\title{
Craniovertebral Junction Arachnoiditis: An Unusual Sequelae to Tuberculous Meningitis
}

Nupur Pruthi ${ }^{1}$ Tarang Kamalkishore Vora ${ }^{1}$ Dhaval P. Shukla ${ }^{1,0}$
Address for correspondence Nupur Pruthi, MCh, Department of Neurosurgery, National Institute of Mental Health and Neurosciences, Bangalore 560029, India, (e-mail: pruthi_nupur@yahoo.co.in).

\author{
Abstract \\ Keywords \\ - foramen magnum \\ arachnoiditis \\ - tuberculous \\ meningitis \\ - posterior fossa \\ decompression \\ - adhesiolysis \\ - craniocervical junction \\ arachnoiditis \\ - craniovertebral junc- \\ tion arachnoiditis
}

Adhesive arachnoiditis at the craniovertebral junction should be suspected in patients with a history of meningitis having delayed onset gradually progressive tetra paresis. Patients can present after an asymptomatic interval of 2 to 20 years. Cardiac gated cine magnetic resonance imaging is useful for its diagnosis. Posterior fossa decompression with upper cervical laminectomy and adhesiolysis appears to be a reasonable treatment for the same. We illustrate two patients who presented to us with gradually progressive spastic tetra paresis; both had prior history of cured tuberculous meningitis.

\section{Introduction}

Craniovertebral junction arachnoiditis (CVJA) is a rare condition that can occur as a consequence of trauma, subarachnoid hemorrhage, meningitis, or any previous posterior fossa surgery. ${ }^{1,2}$ Arachnoiditis at craniovertebral junction following meningitis was first reported in $1968^{1}$ and till date less than 10 cases have been reported in literature. Most of those are tubercular in etiology. In spite of the heavy burden of tubercular meningitis, till date no case of CVJA has been reported from the developing world.

\section{Case Reports}

Case 1: A 26-year-old gentleman came to us with gradually progressive quadriparesis. He was diagnosed with tubercular meningitis 2 years ago. After 7 months of treatment with antitubercular therapy, he was diagnosed to have hydrocephalus for which he underwent placement of a ventriculoperitoneal shunt, following which he had good recovery. After an asymptomatic period of 18 months, he started to develop progressive weakness of all four limbs over a duration of 6 months, and eventually became wheelchair bound. There was spastic quadriparesis with motor power of grade $2 / 5$ in left upper limb and $4 / 5$ in rest of the limbs. Cerebrospinal fluid (CSF) analysis revealed increased proteins $(788 \mathrm{mg} / \mathrm{dL})$ with no cells. Magnetic resonance imaging (MRI) revealed trapped 4th ventricle along with anterior subdural encysted collections at cervicomedullary junction and C2 to C5 cord signal intensity changes. The upper cervical cord was plastered. Brain MRI and rest of spine MRI were normal ( - Fig. 1).

A suboccipital craniectomy, foramen magnum decompression, C1 posterior arch excision, and C2, C3 laminectomy were done. After opening the thickened dura of foramen magnum and upper cervical spinal canal, an opaque adhesive arachnoid layer covering the spinal cord was found. This arachnoid was gently dissected microscopically to free the spinal cord. Multiple openings were made in the anterior subdural space at the cervicomedullary junction to release CSF from multiple loculations. Scarred and closed foramen 


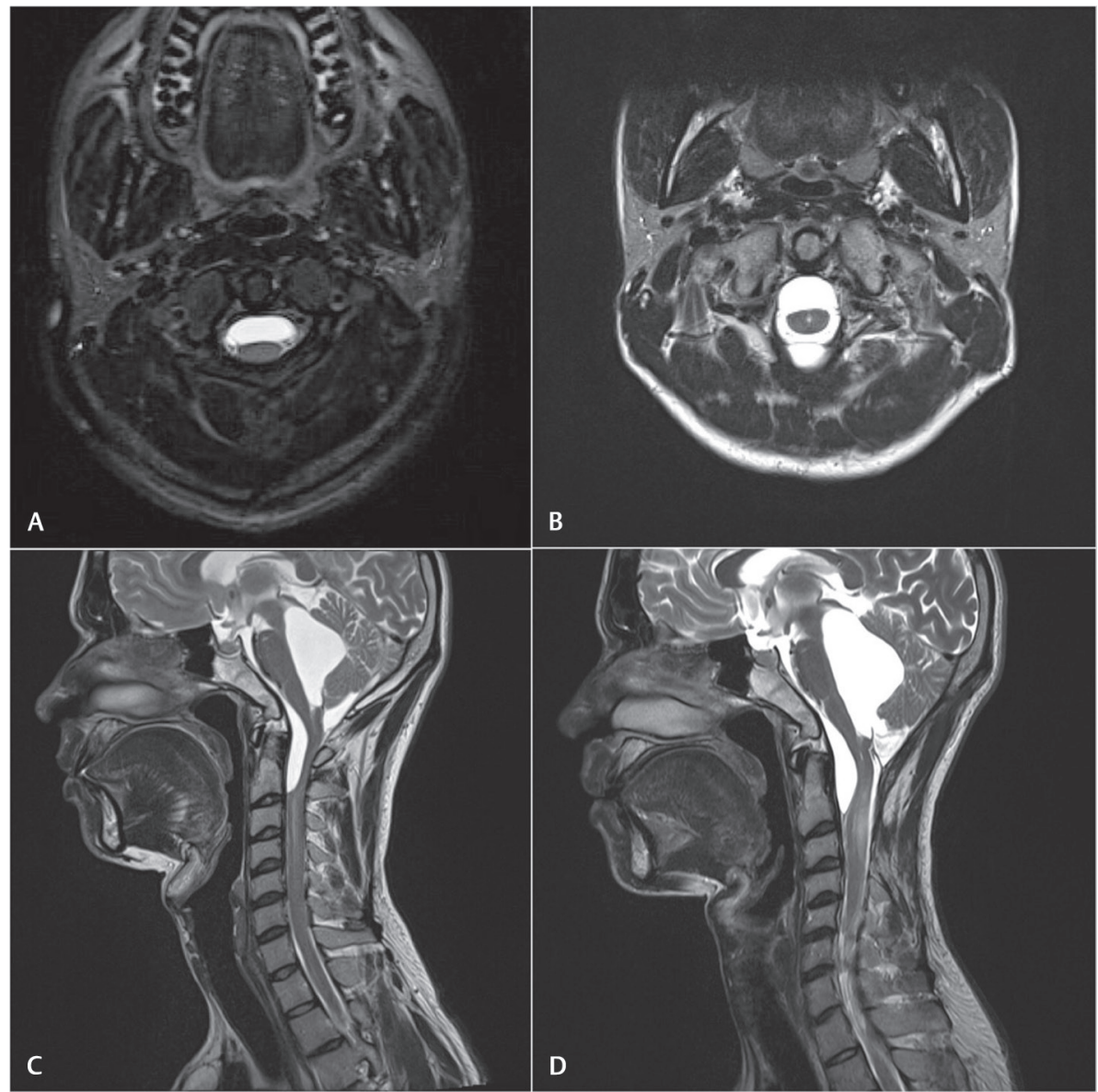

Fig. 1 (A-D) Preoperative(left) and follow-up (right) magnetic resonance imaging T2-weighted images of case 1.

of Magendie was opened and choroid plexus was coagulated. After noting the free pulsatile flow of CSF, expansile duraplasty with fascia lata graft was performed. There was gradual improvement in strength in the upper limbs. At 1-year follow-up patient was ambulant without support. MRI at follow-up revealed increased CSF space at cervicomedullary junction without reduction in the size of 4 th ventricle (-Fig. 1).

Case 2: A 27-year-old gentleman presented with progressive spastic quadriparesis of 8 months duration. He had tuberculous meningitis before 3 years, from which he had recovered completely after antitubercular therapy. Power in both lower and upper limbs was $3 / 5$. CSF analysis revealed elevated proteins $(576 \mathrm{mg} / \mathrm{dL}$ ) with no cells. The MRI scan revealed a subdural collection anterior to cord at cervicomedullary junction with a holocord syrinx. The upper cervical cord was plastered posteriorly at C2 level. Cardiac gated cine MRI revealed poor CSF flow at the cervicomedullary junction posteriorly ( - Fig. 2).

A suboccipital craniectomy, foramen magnum decompression, $\mathrm{C} 1$ posterior arch excision, and C2, C3 laminectomy were done. Similar to previous case thickened opaque arachnoid was noted. Foramen Magendie was open and had good communication. Cervical cord was noted to be swollen. Multiple adhesions between cord and posterior dura were noted at $\mathrm{C} 2$

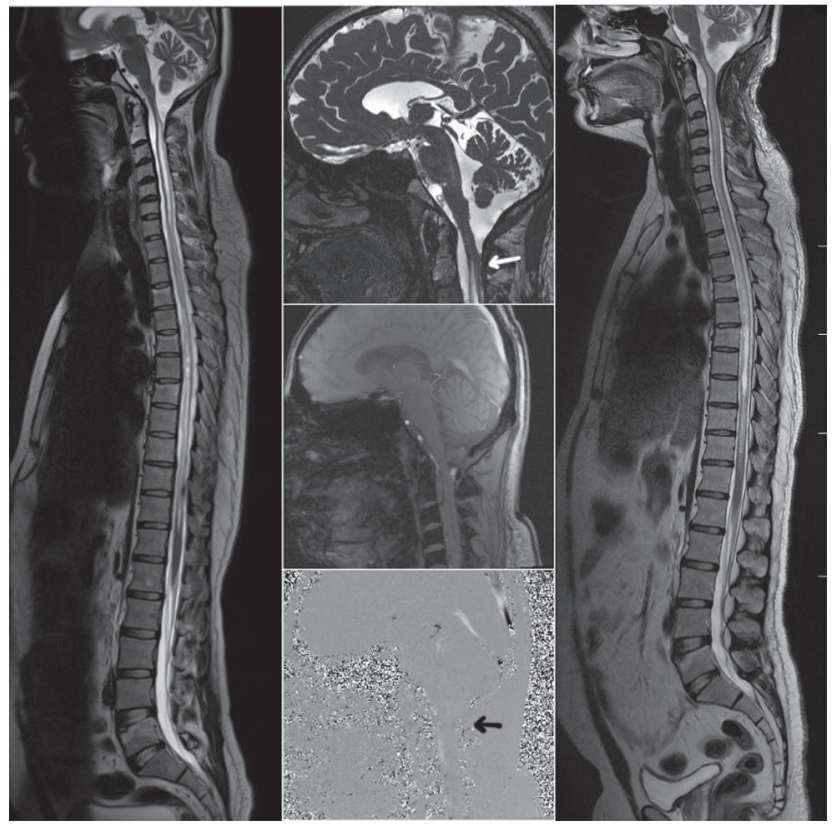

Fig. 2 Preoperative (left) and postoperative (right) magnetic resonance imagings (MRIs) of case 2. Cardiac-gated cine MRI (middle, black arrow) showing decreased flow posteriorly at foramen magnum. Adhesive arachnoiditis at C2 level causing obstruction of cerebrospinal fluid posteriorly (middle, white arrow) 
level that were microsurgically released. Expansile duraplasty with fascia lata graft was performed. At 6 months patient was noted to have reduced spasticity; however, the motor power remained status quo. There was no further progression of disease. Follow-up MRI showed significant reduction in size of the syrinx in the cervical cord ( - Fig. 2)

\section{Discussion}

Eight cases of CVJA post meningitis have been reported till date. Most of these patients were in the 4th decade of their life (-Table 1). Duration of asymptomatic period ranged from 2 to 20 years post meningitis. Most common infective pathology among the reported cases was tuberculosis. Among eight cases, seven underwent posterior fossa decompression. Only three of the operated patients improved, one remained stable and three worsened or died. Poor outcome was seen in patients with longer duration of asymptomatic interval.

Incidence rate of tuberculosis in the developing world is very high and tubercular meningitis is one of its most common extrapulmonary manifestations. In spite of the alarming numbers of tuberculosis cases in South East Asia, arachnoiditis at craniovertebral junction is rarely seen. Reduced awareness and a late presentation of the disease after an unsuspecting interval of good health may be responsible for not recognizing this entity.

The delay in presentation after meningitis could be attributed to the time needed for formation for fibrosis and obstruction of CSF pathways to eventually form a syrinx. Because of the availability of cardiac-gated cine MRI, demonstration of CSF flow obstruction at the foramen magnum has become easier. A recent radiological study revealed that $18.5 \%$ of asymptomatic patients with a history of tuberculous

Table 1 Literature summary of CVJA post meningitis

\begin{tabular}{|c|c|c|c|c|c|c|c|c|}
\hline $\begin{array}{l}\text { Author/year / } \\
\text { country }\end{array}$ & $\begin{array}{l}\text { Patients } \\
\text { age/sex }\end{array}$ & $\begin{array}{l}\text { Asymptomatic } \\
\text { period }(y)\end{array}$ & Symptoms & Etiology & $\begin{array}{l}\text { Diagnostic } \\
\text { modality }\end{array}$ & Syrinx & $\begin{array}{l}\text { Surgical } \\
\text { intervention }\end{array}$ & Outcome \\
\hline $\begin{array}{l}\text { Appleby } \\
\text { et al, 1969; } \\
\text { England }^{1}\end{array}$ & $30 / F$ & 11 & $\begin{array}{l}\text { Gait ataxia, } \\
\text { pain }\end{array}$ & $\begin{array}{l}\text { Tuber- } \\
\text { culous } \\
\text { meningitis }\end{array}$ & Myelogram & Cervical & $\begin{array}{l}\text { PFD + } \\
\text { Torkildsen's } \\
\text { ADL + UCL }\end{array}$ & $\begin{array}{l}\text { Temporary } \\
\text { worsening } \\
\text { post re-ex- } \\
\text { ploration }\end{array}$ \\
\hline $\begin{array}{l}\text { Appleby } \\
\text { et al, 1969; } \\
\text { England }^{1}\end{array}$ & $32 / \mathrm{M}$ & 6 & $\begin{array}{l}\text { Spastic } \\
\text { paraparesis }\end{array}$ & $\begin{array}{l}\text { Tuber- } \\
\text { culous } \\
\text { meningitis }\end{array}$ & Autopsy & C2-T12 & - & - \\
\hline $\begin{array}{l}\text { Giménez- } \\
\text { Roldán et al, } \\
\text { 1974; Spain }\end{array}$ & $33 / \mathrm{M}$ & 20 & $\begin{array}{l}\text { Gait ataxia, } \\
\text { spastic } \\
\text { paraparesis }\end{array}$ & $\begin{array}{l}\text { Tuber- } \\
\text { culous } \\
\text { meningitis }\end{array}$ & $\begin{array}{l}\text { Air ventric- } \\
\text { ulogram }\end{array}$ & C1-T11 & $\begin{array}{l}\text { PFD+ ADL } \\
+ \text { Obex } \\
\text { Plugging }\end{array}$ & $\begin{array}{l}\text { Died after } \\
\text { procedure }\end{array}$ \\
\hline $\begin{array}{l}\text { Klekamp et al, } \\
\text { 2002; Germa- } \\
\text { ny and USA² }\end{array}$ & $38 \pm 12$ & 3 & $\begin{array}{l}\text { Occipital } \\
\text { pain, motor } \\
\text { weakness }\end{array}$ & $\begin{array}{l}\text { Crypto- } \\
\text { coccal } \\
\text { meningitis }\end{array}$ & MRI & Present & $\begin{array}{l}\text { PFD+ ADL } \\
\text { SP Shunt }{ }^{\mathrm{a}}\end{array}$ & $\begin{array}{l}\text { Stable post } \\
\text { re-explora- } \\
\text { tion }\end{array}$ \\
\hline $\begin{array}{l}\text { Klekamp et al, } \\
\text { 2002; Germa- } \\
\text { ny and USA }\end{array}$ & $38 \pm 12$ & 16 & $\begin{array}{l}\text { Motor } \\
\text { weakness }\end{array}$ & Meningitis & MRI & Present & $\begin{array}{l}\text { PFD+ ADL } \\
\text { SP Shunt } \\
\text { PFD+ ADL }\end{array}$ & $\begin{array}{l}\text { Improved } \\
\text { post re- } \\
\text { explora- } \\
\text { tions }\end{array}$ \\
\hline $\begin{array}{l}\text { Klekamp et } \\
\text { al, 2002; } \\
\text { Germany and } \\
\text { USA }^{2}\end{array}$ & $38 \pm 12$ & - & Gait ataxia & Meningitis & MRI & Present & $\mathrm{PFD}+\mathrm{ADL}$ & Improved \\
\hline $\begin{array}{l}\text { Klekamp } \\
\text { et al, 2002; } \\
\text { Germany and } \\
\text { USA }^{2}\end{array}$ & $38 \pm 12$ & 8 & Gait ataxia & Meningitis & MRI & Present & PFD+ ADL & $\begin{array}{l}\text { Recurrence } \\
\text { and died } \\
\text { after } 4 \\
\text { years }\end{array}$ \\
\hline $\begin{array}{l}\text { Klekamp } \\
\text { et al, 2002; } \\
\text { Germany and } \\
\text { USA }^{2}\end{array}$ & $38 \pm 12$ & 3 & $\begin{array}{l}\text { Occipital } \\
\text { pain }\end{array}$ & Meningitis & MRI & Present & Conservative & Stable \\
\hline $\begin{array}{l}\text { Davidoff } \\
\text { et al, } 2017 \text {; } \\
\text { Australia }^{10}\end{array}$ & $40 / \mathrm{F}$ & 2 & $\begin{array}{l}\text { Sensory } \\
\text { distur- } \\
\text { bances and } \\
\text { weakness }\end{array}$ & $\begin{array}{l}\text { Viral } \\
\text { meningitis }\end{array}$ & MRI & C1-T5 & PFD+ ADL & Improved \\
\hline
\end{tabular}

Abbreviations: ADL, adhesiolysis; CVJA, craniovertebral junction arachnoiditis; MRI, magnetic resonance imaging; PFD, posterior fossa decompression; UCL, upper cervical laminectomy.

aRe-exploration due to worsening of symptoms. 
meningitis have radiological features of spinal arachnoiditis. ${ }^{3}$ Early identification by radiological imaging during the convalescence period of tuberculous meningitis may aid in identifying patients prone to develop CVJA.

Arachnoiditis infective or noninfective implies a fibrovascular and cell-mediated reaction, leading to nonspecific scarring of meninges to varying degrees depending on the etiological agent. Organization of exudates after meningitis causes matting of the nerve roots, also the inflammatory reaction induces fibrosis causing adhesions of the spinal cord to the meninges. In such cases of adhesive arachnoiditis, subarachnoid spaces may be irregularly obstructed with the formation of CSF loculations. ${ }^{4}$

In both of our cases, adhesions were located posteriorly along the thecal sac; this may be due to gravity-assisted accumulation of exudates posteriorly during prolonged bed rest. All cases of CVJA reported till date were associated with the presence of syringomyelia due to obstructed CSF flow at the foramen magnum. Unlike the postulated pulsatile intermittent obstruction at foramen magnum in Chiari malformations, CVJA may be associated with continuous obstruction to CSF flow due to scarring and adhesions.

Post infective obliterative endarteritis causing ischemic injury may soften spinal cord leading to cavitation. Also focal scarring due to inflammation may lead to obstruction of the CSF flow, pushing CSF into the central canal of the spinal cord through the Virchow-Robin spaces, which when dilated may coalesce to form a syrinx ${ }^{5,6}$ Recent studies described how the interstitial edema caused by the pia-arachnoid scarring has a major role in the development of syringomyelia in spinal arachnoiditis. Disturbances in venous circulation may interfere with CSF absorption and lead to excessive fluid intake from interstitial spaces. This process could expand intramedullary microcystic lesions and eventually form a syrinx. ${ }^{7.8}$

Earlier studies on posterior fossa decompression for CVJA reported poor patient outcomes; thus, the recommended surgical treatment was limited to shunts. ${ }^{1.9}$ Usage of advanced imaging, microsurgical techniques, limiting unnecessary arachnoid dissection, and lesser blood in surgical field should aid in achieving better patient outcomes. ${ }^{2,10}$ In view of insufficient evidence, surgery at present is only indicated if the patients' neurological status is progressively worsening.

Along with posterior fossa decompression, upper cervical laminectomies are essential to relieve CSF loculations and arachnoid adhesive bands. In patients with extensive arachnoid disease after meningitis, arachnoid dissection is associated with the potential risk of damaging small perforating arteries. Careful microsurgical techniques should aid in preventing them. Large autologous fascia lata grafts were used for duraplasty, as it has less tissue reaction and less adhesions. The excess cost of good quality allografts is also an important factor in choosing autologous grafts in the developing world. Shunting of the syrinx should be considered only in those cases in which the CSF flow obstruction cannot be corrected, as in most cases posterior fossa decompression with adequate adhesiolysis would suffice. We believe that syrinx diversion methods should only be used in case of failure to correct the primary cause of obstruction in CSF pathway. Inadequate adhesiolysis, done to avoid undue damage to critical structures, may be responsible for the high recurrence rates and re-explorations (42.9\%) (-Table 1 ).

Among our patients, better outcome in case 1 could be attributed to shorter duration of asymptomatic interval, absence of syrinx, and better neurological grade preoperatively. With such meagre number of reported cases, we can only speculate if earlier intervention to restore flow of CSF across the craniovertebral junction prior to syrinx formation would yield better outcomes.

\section{Conclusion}

CVJA should be suspected in patients with a prior history of meningitis when they present with worsening of neurological status after a period of good recovery. Only patients with progressive neurological deficits should be offered surgery. Goal of surgery is to achieve clear passage for flow of CSF and to arrest progression of neurological insult. Surgery-related outcomes should improve with timely detection, early intervention, and microsurgical techniques.

\section{Conflict of Interest}

None declared.

\section{References}

1 Appleby A, Bradley WG, Foster JB, Hankinson J, Hudgson P. Syringomyelia due to chronic arachnoiditis at the foramen magnum. J Neurol Sci 1969;8(3):451-464

2 Klekamp J, Batzdorf U, Samii M, Bothe HW. Treatment of syringomyelia associated with arachnoid scarring caused by arachnoiditis or trauma. J Neurosurg 1997;86(2):233-240

3 Srivastava T, Kochar DK. Asymptomatic spinal arachnoiditis in patients with tuberculous meningitis. Neuroradiology 2003;45(10):727-729

4 Dastur D, Wadia NH. Spinal meningitides with radiculo-myelopathy. 2. Pathology and pathogenesis. J Neurol Sci 1969;8(2):261-297

5 Caplan LR, Norohna AB, Amico LL. Syringomyelia and arachnoiditis. J Neurol Neurosurg Psychiatry 1990;53(2):106-113

6 Fehlings MG, Bernstein M. Syringomyelia as a complication of tuberculous meningitis. Can J Neurol Sci 1992;19(1):84-87

7 Josephson A, Greitz D, Klason T, Olson L, Spenger C. A spinal thecal sac constriction model supports the theory that induced pressure gradients in the cord cause edema and cyst formation. Neurosurgery 2001;48(3):636-645, discussion 645-646

8 Koyanagi I, Iwasaki Y, Hida K, Houkin K. Clinical features and pathomechanisms of syringomyelia associated with spinal arachnoiditis. Surg Neurol 2005;63(4):350-355, discussion 355-356

9 Giménez-Roldán S, Esteban A, Benito C. Communicating syringomyelia following cured tuberculous meningitis. J Neurol Sci 1974;23(2):185-197

10 Davidoff CL, Liu S, Wong JHY, Koustais S, Rogers JM, Stoodley MA. Treatment of syringomyelia in patients with arachnoiditis at the craniocervical junction. World Neurosurg 2017; 107:565-573 